\title{
KAJIAN SOSIAL-EKONOMI DALAM PELAKSANAAN SISTEM INTEGRASI SAPI-KELAPA SAWIT (SISS) DI PT AGRICINAL KAB. BENGKULU UTARA
}

\author{
Agus Purwoko \\ Bambang Sumantri \\ Jurusan Sosial Ekonomi Pertanian Fakultas Pertanian Universitas Bengkulu
}

\begin{abstract}
The research was conducted to study factors that correlated with harvest labours' motivation to join the program of systematic cow cattle integration in oil palm plantation (SISS), to investigate the harvest labours' net income from SISS and its contribution to family income, and to examine factors that were influencing the return rate of credit. The research was conducted in PT Agricinal, an oil palm plantation in North Bengkulu Regency. The respondents for the research consisted of 83 harvest labours were selected from 3 afdellings proporsionally using simple random sampling method. Data were analyzed using Spearman's Rank-Order correlation coefficient and multiple linear regressions. Harvest labours' age, net income from SISS, the number of dependency family, empathi, and dogmatism were significantly correlated with the labours' motivation to join the program of SISS. The average of harvest labours' monthly net income from SISS was Rp. 1.23 million and its contribution to family income was 98.71 percents. While the return rate of credit was only 43.27 percent and it was significantly influenced by the harvest labours' education and the total of credit. PT Agricinal should be maintaining the harmony relationship with harverst labours in order to improve their work motivation. In addition, the regulation of SISS program should be conveyed not only in oral but also in writing in order to guarantee the harvest labours to do their job.
\end{abstract}

Key word: SISS, labours motivation, labours net income, and the return rate of credit

\section{PENDAHULUAN}

PT Agricinal merupakan perusahaan inti dari perkebunan kelapa sawit dengan pola PIR yang terletak di Kabupaten Bengkulu Utara. Sejak tahun 1997 mulai dikembangkan ternak sapi di kebun inti. Sistem integrasi ternak sapi dengan tanaman kelapa sawit (SISS) dapat dijadikan salah satu alternatif potensial yang dapat dilaksanakan dalam upaya mendukung pengembangan agribisnis peternakan sekaligus agribisnis perkebunan di Indonesia. Dari aspek teknis sistem integrasi sapi-kelapa sawit cukup aplikatif, dari aspek ekonomi dinilai cukup menguntungkan, dan dari aspek sosial cukup dapat diterima. Pada umumnya, motivasi pemanen dalam mengikuti program SISS ditentukan oleh faktor-faktor dari dirinya sendiri (internal factors) yang berkaitan 
dengan tujuan apa yang ingin dicapai dengan program SISS serta bagaimana mencapai tujuan tersebut dan faktor-faktor pendukung yang berasal dari luar dirinya (external factors), misalnya jumlah sapi yang disediakan perusahaan dan berbagai kebijakan tentang perkreditan.

Tujuan utama dari introduksi ternak sapi pada perkebunan sawit yang dilakukan PT Agricinal adalah untuk efisiensi pengangkutan hasil panen tandan buah segar (TBS). Pemeliharaan ternak sapi di areal perkebunan kelapa sawit akan mendapatkan nilai tambah dari hasil perkembangan ataupun dari hasil peningkatan berat badannya serta kotorannya, dimana nilai tambah tersebut akan sangat potensial untuk meningkatkan pendapatan pemanen secara keseluruhan. Pendapatan yang diperoleh pemanen melalui program SISS akan sangat berpengaruh terhadap pendapatan rumah tangga pemanen secara keseluruhan.

Penyaluran sapi di kebun inti PT Agricinal memakai dua pola kredit, yaitu Senaba Makmur (SM) dan Ketahanan Pangan (KP) dengan bunga sebesar 19,5\% per tahun dengan jangka waktu pengembalian 4 tahun. Dalam penyaluran kredit sapi kepada pemanen, PT Agricinal mempunyai kewajiban dalam pembinaan dan pelayanan sehingga terjadi proses alih teknologi pemeliharaan sapi di dalam kebun sawit.

Penelitian ini bertujuan untuk: (1) Mengkaji motivasi pemanen mengikuti program Sistem Integrasi Sapi-Kelapa Sawit (SISS) dan faktor-faktor yang berhubungan dengannya, (2) Mengkaji pendapatan pemanen dari program SISS dan kontribusinya terhadap pendapatan rumah tangganya, dan (3) Mengkaji tingkat pengembalian kredit pada program SISS oleh pemanen dan faktor-faktor yang mempengaruhinya.

\section{METODOLOGI PENELITIAN}

Penelitian ini menggunakan metode survai yaitu penelitian lapangan yang menggunakan quesioner (daftar pertanyaan) sebagai alat pengumpul data yang pokok. Lokasi penelitian 
ditentukan secara sengaja (purposive) yaitu PT Agricinal sebagai satu-satunya perkebunan swasta kelapa sawit di Propinsi Bengkulu yang menyelenggarakan program SISS sejak tahun 1997.

Penentuan responden dilakukan melalui dua tahapan (two stages sampling). Pertama, dari 10 afdeling yang sudah berproduksi dikelompokkan berdasarkan tahun tanam kelapa sawitnya dan dari masing-masing kelompok ditentukan satu afdeling secara sengaja (purposive sampling) dengan pertimbangan: (a) lokasi afdeling dengan kantor perusahaan dan (b) pemanennya mengambil kredit SISS dengan dua pola (Senaba Makmur/SM dan Ketahanan Pangan/KP). Tahap kedua, dari populasi ketiga afdeling terpilih, selanjutnya dengan menggunakan metode alokasi proporsional (Nazir 1999) diperoleh 83 responden. Teknik pemilihan responden untuk masing-masing afdeling ditentukan secara proporsional random sampling.

Untuk menganalisis tujuan pertama, yakni motivasi pemanen dalam mengikuti program SISS dan beberapa karakteristik pemanen yang berhubungan dengan motivasi tersebut digunakan uji korelasi rank Spearman dengan formula sebagai berikut:

$$
r_{s}=1-\frac{6 \sum_{i=1}^{n} d_{i^{2}}}{n^{3}-n}
$$

dimana:

$r_{\mathrm{s}}=$ koefisien korelasi rank Spearman

$\mathrm{n}=$ jumlah responden

$\mathrm{d}_{\mathrm{i}}=$ selisih antara ranking variabel bebas dengan ranking variabel terikat untuk responden ke -i

Untuk mengetahui nyata atau tidaknya hubungan kedua variabel dilakukan uji-t dengan tingkat kepercayaan $95 \%$.

Untuk mengetahui tujuan kedua yakni besarnya pendapatan rumah tangga pemanen diperhitungkan dengan menjumlahkan seluruh pendapatan yang diperoleh, baik dari program SISS (upah panen, perkembangan dan pertambahan berat badan sapi, dan kotoran ternak sapi) 
maupun pendapatan dari luar program SISS (buruh, jasa, dagang, dan sebagainya). Sementara untuk mengukur besarnya kontribusi pendapatan dari program SISS terhadap pendapatan total rumah tangga pemanen dengan rumus sebagai berikut:

$$
\text { Kont. pendp. SISS = } \frac{\text { Pendp. dari SISS }}{\text { Total pendp. RT }}
$$

dengan klategori sebagai berikut : sangat rendah ( $\leq 20 \%)$, rendah $(21-40 \%)$, sedang/cukup (41$60 \%)$, tinggi (61-80\%), dan sangat tinggi $(\geq 81 \%)$.

Untuk menganalis faktor-faktor yang berpengaruh terhadap tingkat pengembalian kredit SISS (tujuan ketiga) digunakan model regresi linier berganda dengan formula sebagai berikut:

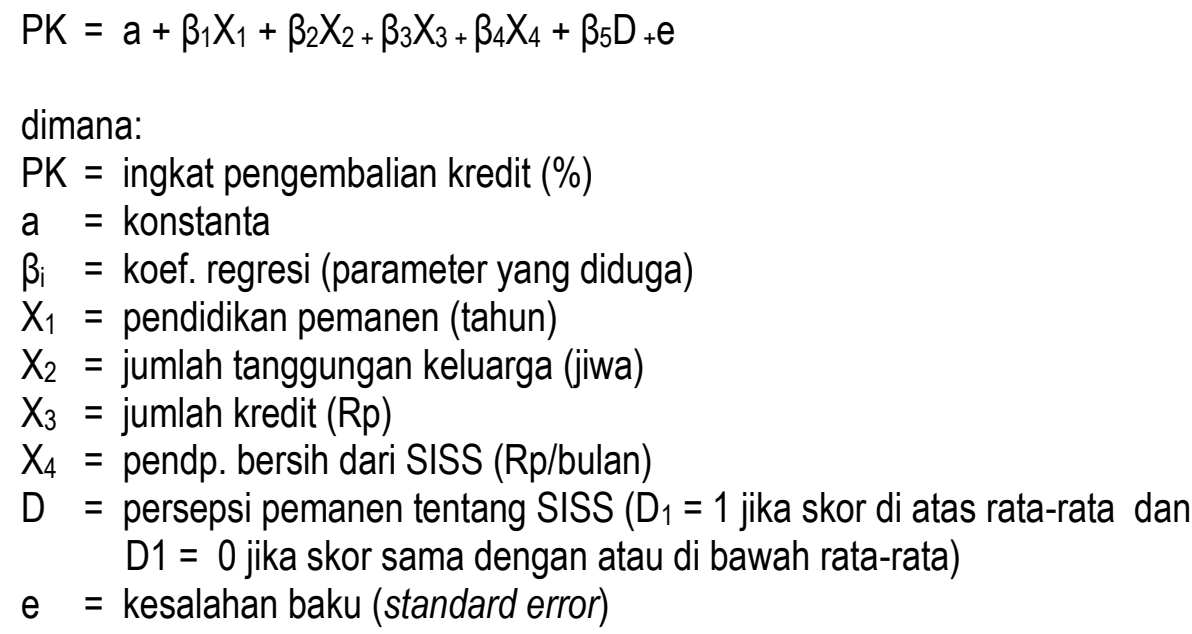

Untuk mengetahui apakah variabel-variabel bebas yang digunakan dalam model secara bersama-sama mempunyai pengaruh terhadap variabel terikat digunakan uji $\boldsymbol{F}$ dan $\boldsymbol{u} \boldsymbol{j i} \boldsymbol{t}$ bertujuan untuk mengetahui apakah variabel bebas secara parsial (individu) berpengaruh terhadap variabel terikat, dimana kedua uji tersebut menggunakan tingkat kepercayaan sebesar $95 \%$.

\section{HASIL DAN PEMBAHASAN}

\section{Motivasi Keikutsertaan Pemanen dalam Program SISS}

Hasil estimasi hubungan antara beberapa variabel karakteristik pemanen dengan motivasi keikutsertaan mereka dalam program SISS disajikan dalam tabel berikut ini. 
Tabel 1. Estimasi Variabel-variabel yang Berhubungan dengan Motivasi Keikutsertaan Pemanen dalam Program SISS

\begin{tabular}{lcc}
\hline \multicolumn{1}{c}{ Variabel yang diestimasi } & $\mathbf{r}_{\mathbf{s}}$ hitung & t hitung \\
\hline $\mathrm{X}_{1}$. Umur pemanen & 0,409 & $\left.4,0338^{*}\right)$ \\
$\mathrm{X}_{2}$. Pendapatan pemanen & 0,614 & $\left.7,0010^{*}\right)$ \\
$\mathrm{X}_{3}$. Jumlah tanggungan keluarga pemanen & 0,297 & $\left.2,7993^{*}\right)$ \\
$\mathrm{X}_{4}$. Pengalaman kerja pemanen & 0,185 & 1,6942 \\
$\mathrm{X}_{5}$. Tingkat empathi & 0,778 & $\left.11,1450^{*}\right)$ \\
$\mathrm{X}_{6 .}$ Tingkat dogmatis & 0,802 & $\left.12,0839^{*}\right)$ \\
\hline
\end{tabular}

*) berhubungan nyata pada taraf kepercayaan $95 \%$

$\mathrm{t}(0,05 ; 81)=+/-1,9930$

Sumber: Analisis data primer (2006).

Analisis menunjukkan bahwa umur pemanen berhubungan nyata dengan motivasi keikutsetaan mereka dalam program SISS, artinya semakin tua umur pemanen maka motivasi mereka dalam mengikuti program SISS semakin tinggi atau sebaliknya. Umumnya pemanen yang berumur relatif tua mempunyai motivasi kerja yang lebih tinggi dan bertanggung jawab untuk memenuhi kebutuhan keluarganya, sehingga dengan mengikuti program SISS memberikan peluang untuk meningkatkan pendapatannya. Selain itu, dengan mengikuti program SISS akan meringankan tenaga fisiknya yang semakin lemah dalam mengangkut TBS dari kebun ke TPH dengan bantuan tenaga sapi kredit untuk menarik gerobak.

Pendapatan pemanen berhubungan nyata dengan motivasi keikutsertaan mereka dalam program SISS, artinya semakin besar pendapatan yang diperoleh pemanen dari PT Agricinal maka semakin tinggi motivasi mereka dalam mengikuti program SISS atau sebaliknya. Hasil penelitian menunjukkan bahwa rerata pendapatan kotor yang diperoleh setiap pemanen setiap bulannya cukup besar yaitu Rp 1.497.181,-. Dengan jumlah potongan (angsuran pokok kredit SISS dan pinjaman koperasi) sebesar Rp 258.812,-, maka diperoleh pendapatan bersih sebesar Rp 1.238.369,-. Pemanen menyatakan bahwa dengan mengikuti program SISS terjadi peningkatan pendapatan yang cukup signifikan dibandingkan sebelumnya.

Jumlah tanggungan keluarga berhubungan nyata dengan motivasi keikutsertaan pemanen dalam program SISS, artinya semakin besar jumlah tanggungan keluarga seorang pemanen maka 
akan semakin besar motivasi kerjanya karena beban tanggung untuk memenuhi kebutuhan keluarganya, sehingga semakin besar pula motivasinya untuk mengikuti program SISS karena mampu meningkatan pendapatannya.

Pengalaman kerja pemanen sebagai pendodos TBS tidak berhubungan nyata dengan motivasi keikutsetaan mereka dalam program SISS. Kondisi ini dikarenakan setiap pemanen mendapatkan petunjuk melalui penyuluhan yang diberikan oleh perusahaan mengenai teknik pendodosan dan pengangkutan TBS, dimana setiap pemanen harus mengikuti petunjuk dan aturan yang ditetapkan perusahaan. Hal ini menyebabkan keterampilan pemanen dalam mendodos dan mengangkut TBS relatif sama, meskipun mereka mempunyai pengalaman kerja yang bervariasi. Selain itu, perusahaan juga tidak mensyaratkan pengalaman kerja sebagai indikator diterima atau tidaknya pemanen ikut dalam program SISS, tetapi setiap pemanen dalam kebun inti harus mengikutinya. Hasil analisis menunjukkan bahwa tingkat empati pemanen terhadap sesamanya dan perusahaan berhubungan nyata dengan motivasi mereka dalam mengikuti program SISS. Dalam pola kemitraan SISS, dimana masing-masing pihak (pemanen dan PT Agricinal) mempunyai hak dan kewajiban yang saling menguntungkan. Para pemanen memahami bahwa hubungan kerjasama itu harus tetap dijaga untuk kepentingan bersama, dimana perusahaan mendapatkan jasa karyawan sebagai buruh panen dan pemanen pun mendapatkan gaj/upah dari perusahaan sebagai balas jasanya, sehingga setiap pemanen harus melakukan kerjasama dengan sesama pemanen lainnya.

Tingkat dogmatis mempunyai hubungan yang nyata dengan motivasi pemanen dalam mengikuti program SISS. Para pemanen berpendapat bahwa program SISS ditujukan untuk meningkatkan kesejahteraan pemanen sekaligus meningkatkan keuntungan perusahaan. Oleh karena itu, setiap pemanen sebagai karyawan perusahaan harus menghargai dan menghormati pimpinannya dengan mengikuti berbagai peraturan yang ditetapkan perusahaan. Hal ini 
merupakan kondisi yang mengikat pemanen dalam melaksanakan kewajibannya sebagai peserta program SISS.

\section{Pendapatan Pemanen dari Program SISS}

Salah satu tujuan dari program SISS adalah meningkatkan pendapatan pemanen melalui penerimaan upah panen. Hasil penelitian mengenai pendapatan pemanen dari program SISS dan kontribusinya terhadap pendapatan keluarga disajikan pada Tabel 2.

Tabel 2. Rerata Pendapatan Pemanen dari Program SISS dan Kontribusinya terhadap Pendapatan Keluarga

\begin{tabular}{clc}
\hline No. Sumber Pendapatan & $\begin{array}{c}\text { Rerata Pendapatan } \\
\text { (Rp/bulan) }\end{array}$ \\
\hline 1. & Pendapatan dari program SISS (buruh panen) & 1.497 .181 \\
& a. Gaji pokok & 607.505 \\
& b. Subsidi & 15.505 \\
& C. Premi produksi & 782.020 \\
& d. Upah lembur & 91.910 \\
2. Jumlah potongan pinjaman & 258.812 \\
3. Pendapatan bersih dari program SISS & 1.238 .369 \\
4. Pendapatan dari non SISS & 250.602 \\
5. Pendapatan bersih keluarga (3+ 4) & 1.488 .971 \\
6. Kontribusi pendapatan dari SISS terhadap & $98,71 \%$ \\
\hline
\end{tabular}

Sumber: Analisis data primer (2006).

Rerata pendapatan pemanen dari program SISS adalah Rp 1.497.181,- per bulan, yang meliputi empat komponen yaitu: gaji pokok, subsidi, premi produksi, dan upah lembur. Gaji pokok yang diterima pemanen sebagai karyawan PT Agricinal bervariasi antara Rp 474.720,- sampai dengan Rp 639.840,- setiap bulannya berdasarkan pengalaman kerjanya di perusahaan. Subsidi juga diberikan perusahaan kepada pemanen dengan kriteria sebagai berikut: $\operatorname{Rp} 30.000$,(pemanen dengan anggota keluarga $>3$ orang), Rp. 21.000,- (pemanen dengan anggota keluarga sebanyak 3 orang), dan Rp 12.000,- (pemanen dengan anggota keluarga $<3$ orang). Premi produksi diberikan kepada pemanen jika yang bersangkutan berhasil memanen TBS lebih besar dari pada produksi normal (PN) yang ditetapkan oleh perusahaan. Semakin besar kelebihan 
produksi yang dipanen, maka akan semakin besar pula premi yang diterimanya. Upah lembur diberikan kepada pemanen yang melakukan kerja lembur, dimana besarnya adalah Rp 45.000,per hari kerja.

Hasil sampingan dari kegiatan SISS yang berupa kotoran ternak tidak termasuk dalam pendapatan bersih tersebut. Hal ini dikarenakan kotoran ternak yang dikumpulkan harus disetorkan kepada perusahaan untuk membayar bunga pinjaman kredit sapi. Kotoran ternak dihargai oleh perusahaan sebesar Rp 2.000,- per karung yang bobotnya sekitar $40 \mathrm{~kg}$. Apabila nilai seluruh kotoran ternak melebihi nilai bunga kredit sapi yang harus dibayar setiap bulannya, maka kelebihannya diperhitungkan untuk mengurangi sisa kredit bulan berikutnya. Saat penelitian dilakukan tidak ada seorang pun pemanen yang menjual sapi hasil pengembangan kepada perusahaan, sehingga pendapatan sampingan yang diperoleh dari kegiatan SISS tidak ada.

Jumlah potongan sebesar Rp 258.812,- per bulan terdiri dari angsuran pokok kredit sapi pola SM sebesar Rp 50.000,- dan sisanya merupakan pinjaman kepada koperasi karyawan untuk kebutuhan konsumsi pemanen dan keluarganya. Dengan demikian, pendapatan bersih yang diperoleh pemanen dari program SISS adalah Rp 1.238.369,- per bulan.

Pendapatan dari kegiatan di luar SISS sebesar Rp. 250.602,- per bulan diperoleh dari usaha warung manisan dan ternak ayam buras yang biasanya dilakukan oleh isteri yang dibantu anakanaknya di rumah. Dengan demikian, total pendapatan keluarga pemanen sebesar Rp 1.488.971,- per bulan.

Hasil analisis menunjukkan bahwa kontribusi pendapatan pemanen dari SISS terhadap pendapatan keluarga besarnya $98,71 \%$. Hal ini memberikan indikasi bahwa pekerjaan sebagai pemanen TBS merupakan andalan utama bagi pemenuhan kebutuhan hidup keluarga pemanen. Oleh karena itu, para pemanen selalu berusaha untuk memperoleh hasil panenan melebihi PN dengan harapan memperoleh premi produksi dari perusahaan. 


\section{Tingkat Pengembalian Kredit Sapi Pola Senaba Makmur (SM)}

PT Agricinal memberlakukan dua pola penyaluran kredit sapi bagi pemanen, yaitu pola lama dan pola baru "Ketahanan Pangan" (KP). Penyaluran kredit dengan pola SM "Senaba Makmur" (SM) dengan tingkat bunga 19,5\% per tahun (untuk bank $=18 \%$ dan untuk koperasi $=$ 1,5\%) dimana waktu pengembaliannya 4 tahun, sedangkan penyaluran kredit sapi dengan pola KP dilaksanakan sejak tahun 2003 yang lalu. Tingkat pengembalian kredit dalam penelitian ini adalah tingkat pengembalian kredit sapi dengan pola SM sejak tahun 1997 dan dilakukan oleh Koperasi Karyawan. Jumlah kredit yang dianalisa adalah sisa kredit terhitung sejak 1 April 2005, sedangkan jumlah angsuran kreditnya periode 1 April 2005 s/d 30 April 2006 yang terdiri dari angsuran pokok kredit dan beban bunganya. Sementara itu, tingkat pengembalian kredit merupakan persentase dari angsuran kredit terhadap jumlah kreditnya.

Variabel-variabel bebas secara simultan memberikan pengaruh nyata terhadap tingkat pengembalian kredit (Tabel 3). Besarnya nilai koefisien determinasinya $\left(R^{2}\right)$ adalah 0,615 artinya secara simultan variabel-variabel bebas memberikan kontribusi sebesar $61,5 \%$ terhadap tingkat pengembalian kredit, sedangkan sisanya dipengaruhi variabel-variabel lain yang tidak dimasukkan dalam model ini.

Tabel 3. Estimasi Variabel-Variabel yang Mempengaruhi Tingkat Pengembalian Kredit Sapi Pola SM

\begin{tabular}{|c|c|c|c|c|}
\hline No. & Variabel bebas & $\begin{array}{l}\text { Koefisien } \\
\text { Regresi }\end{array}$ & $\begin{array}{l}\text { Standard } \\
\text { Error }\end{array}$ & $t_{\text {hitung }}$ \\
\hline 1. & Konstanta & 0,566 & & 3,779 \\
\hline 2. & $\mathrm{X}_{1}$. Pendidikan formal pemanen & $-0,014$ & 0,006 & $-2,106$ * \\
\hline 3. & $\mathrm{X}_{2}$. Jumlah tanggungan keluarga & $-0,013$ & 0,010 & $-1,247$ \\
\hline 4. & $\mathrm{X}_{3 .}$ Jumlah kredit SM & $-6,3 \mathrm{E}-008$ & 0,000 & $-9,495$ * \\
\hline 5. & $\mathrm{X}_{4}$. Pendapatan bersih dari SISS & $1,88 \mathrm{E}-008$ & 0,000 & 0,779 \\
\hline 6. & D. Persepsi pemanen ttg SISS & 0,042 & 0,131 & 0,319 \\
\hline \multicolumn{5}{|c|}{$\begin{array}{l}R^{2}=0,615 \\
F_{\text {hitung }}=24,652\end{array}$} \\
\hline \multicolumn{5}{|c|}{$\begin{aligned} \text { Keterangan: } & { }^{*} \text { nyata pada taraf kepercayaan } 95 \% \\
& F(0,05 ; 5,77)=2,35 \text { dan } \mathrm{t}(0,05 ; 77)=+/-1,9943\end{aligned}$} \\
\hline
\end{tabular}

Sumber: Analisis data primer (2006). 
Koefisien regresi variabel pendidikan formal nilainya sebesar $-0,014$ dan berpengaruh nyata terhadap tingkat pengembalian kredit sapi SISS, artinya semakin tinggi tingkat pendidikan formal pemanen maka tingkat pengembalian kreditnya semakin kecil atau sebaliknya. Pada umumnya pemanen yang mempunyai pendidikan relatif tinggi (SLTA) mempunyai wawasan yang lebih luas dibandingkan dengan pemanen yang pendidikannya rendah, sehingga mereka mempunyai keberanian untuk mengambil kredit sapi lebih banyak dibandingkan pemanen yang berpendidikan rendah. Hal ini dengan pertimbangan bahwa angsuran pokok pinjaman yang ditetapkan oleh perusahaan sebesar Rp. 50.000,- per bulan dinilai sangat kecil, sehingga sangat meringankan mereka dalam membayarnya. Kondisi ini mengakibatkan adanya kecenderungan tingkat pengembalian kredit sapi SISS akan semakin kecil. Hasil ini sesuai dengan penelitian Farial et al (1997) yang menyatakan bahwa pendidikan formal berpengaruh nyata terhadap kelancaran pengembalian kredit investasi usahatani kelapa hibrida pada proyek TCSDP di Lampung.

Jumlah tanggungan keluarga nilai koefisien regresinya bertanda negatif $(-0,013)$, sehingga ada kecenderungan semakin besar jumlah tanggungan keluarga semakin kecil tingkat pengembalian kreditnya. Variabel ini tidak berpengaruh nyata terhadap tingkat pengembalian kredit sapi SISS. Artinya, banyak sedikitnya jumlah tanggungan keluarga tidak mempengaruhi tingkat pengembalian kredit pemanen. Angsuran pokok kredit dipotong langsung oleh perusahaan dari gaji/upah pemanen yang besarnya Rp 50.000 setiap bulannya, sedangkan pembayaran bunganya berasal dari hasil penjualan kotoran ternaknya. Oleh karena itu, gaji/upah yang diterima pemanen merupakan gaji/upah bersih yang dibawa pulang ke rumah (take home pay) untuk memenuhi kebutuhan keluarganya. Hasil penelitian ini seiring dengan penelitian Suwarno (2002), tetapi bertentangan dengan penelitian Farial et al (1997). 
Jumlah kredit berpengaruh nyata secara negatif terhadap tingkat pengembalian kredit sapi SISS pola SM. Artinya, semakin besar nilai kredit yang diambil pemanen maka semakin kecil tingkat pengembalian kreditnya, dan sebaliknya. Penelitian ini memberikan indikasi bahwa semakin jauh periode pengambilan kreditnya dari 1 April 2005 maka semakin kecil jumlah sisa kreditnya, atau sebaliknya semakin dekat periode pengambilan kreditnya dengan tanggal tersebut maka semakin besar jumlah sisa kreditnya. Dengan demikian wajar jika semakin kecil jumlah kreditnya (sisa kredit) maka tingkat pengembaliannya semakin besar, atau sebaliknya semakin besar jumlah kreditnya maka semakin kecil tingkat pengembaliannya.

Pendapatan bersih dari SISS tidak berpengaruh nyata terhadap tingkat pengembalian kredit sapi. Pendapatan bersih ini merupakan selisih antara gaj/upah kotor dikurangi dengan angsuran pokok kredit sapi sebesar Rp 50.000,- dan pinjaman koperasi. Pembayaran bunga kredit berasal dari prestasi pupuk kandang (PPK). Jika PPK melebihi pembayaran bunga pinjaman, maka sisanya dapat digunakan untuk mengurangi pokok kreditnya. Hasil penelitian menunjukkan tidak ada satu pun pemanen yang mengangsur pokok kredit melebihi yang ditetapkan perusahaan melalui potongan gaj/upah yang lebih besar dan dari pendapatan non SISS. Pendapatan bersih dari SISS dipergunakan untuk memenuhi kebutuhan keluarganya. Dengan demikian, pendapatan bersih dari SISS tidak mempunyai pengaruh nyata terhadap tingkat pengembalian kredit sapi. Hasil penelitian ini seiring dengan penelitian Suwarno (2002), tetapi bertentangan dengan penelitian Farial et al (1997).

Hasil estimasi menunjukkan bahwa persepsi tentang SISS tidak berpengaruh nyata terhadap tingkat pengembalian kredit sapi SISS. Perusahaan dalam menerima pembayaran angsuran pokok dan bunga kredit sapi SISS tidak mempertimbangkan baik buruknya persepsi pemanen tentang program SISS, tetapi memotong langsung gaji/upah setiap pemanen sebesar Rp 50.000,- per bulan, sedangkan pembayaran bunga kredit melalui hasil penjualan kotoran 
ternaknya. Dengan demikian persepsi pemanen tidak berpengaruh nyata terhadap besar kecilnya tingkat pengembalian kredit yang diambil pemanen.

\section{KESIMPULAN DAN SARAN}

Dari hasil penelitian dan pembahasan menghasilkan beberapa kesimpulan, yaitu sebagai berikut:

a) Motivasi keikutsertaan pemanen dalam program SISS pada PT Agricinal dikarenakan program SISS mampu meningkatkan taraf kehidupannya dan kewajibannya sebagai karyawan perusahaan. Umur pemanen, pendapatan bersih dari SISS, jumlah tanggungan keluarga, tingkat empati, dan tingkat dogmatis merupakan faktor-faktor yang berhubungan secara nyata dengan motivasi keikutsertaan dalam program SISS.

b) Rerata pendapatan bersih yang diperoleh pemanen dari program SISS adalah $\mathrm{Rp} 1.238 .369$,/bulan dan memberikan kontribusi yang signifikan yaitu sebesar $98,71 \%$ terhadap pendapatan keluarga.

c) Tingkat pengembalian kredit sapi pola SM (Senaba Makmur) periode 1 April 2005 s/d 30 April 2006 sebesar 43,27\%. Pendidikan formal pemanen dan jumlah kredit berpengaruh secara nyata terhadap tingkat pengembalian kredit sapi pola SM.

Saran-saran yang dapat disampaikan dalam penelitian ini adalah sebagai berikut:

a) PT Agricinal perlu mempertahankan hubungan yang harmonis dengan para pemanen melalui pola kekeluargaan agar motivasi mereka tetap terjaga. Dengan motivasi yang tinggi untuk tetap mengikuti program SISS, maka kesejahteraan keluarga pemanen akan semakin meningkat.

b) Peraturan tentang pelaksanaan program SISS sebaiknya tidak hanya disampaikan secara lisan, tetapi juga harus diberikan secara tertulis kepada para pemanen sehingga mereka akan lebih nyaman dalam melaksanakan program. 
c) Pertemuan antara petugas peternakan dengan para pemanen sebaiknya lebih diarahkan pada pemecahan masalah yang sedang dihadapi pemanen dalam pengadopsian teknologi pemeliharaan sapi.

\section{DAFTAR PUSTAKA}

Farial H, Hasyim Al dan Irfan M. 1997. Analisis Faktor-faktor yang Mempengaruhi Kelancaran Pengembalian Kredit Investasi Usahatani Kelapa Hibrida pada Proyek TCSDP Propinsi Lampung. JPP IX(8):17-26.

Nazir M. 1999. Metode Penelitian. Ghalia Indonesia. Jakarta.

Suwarno, P. 2002. Faktor-faktor yang Mempengaruhi Pengambalian Kredit Usahatani Pola Khusus Padi Sawah MT 1997/1998 di Desa Tulus Rejo, Pekalongan, Lampung Timur. Jurnal Wacana Pertanian I(1):30-35. 